\title{
English Learning Achievement of Multilingual Learners Through Digital Literacy Practices
}

\author{
Fauris Zuhri
}

English Department of Universitas Negeri Surabaya Indonesia

Email: fauriszuhri@unesa.ac.id

\begin{abstract}
Developing and implementing digital literacy practices for multilingual learners can gradually enhance their achievement of learning English. They have different first language backgrounds by developing and implementing digital literacy practices in multilingual learners, progressively, but they are literate digitally. They can improve their learning of English achievement. This article aims to describe how multilingual learners develop and implement digital literacy practices to improve their English learning achievement. The researcher applied observation sheets and field notes to find out the data. The subjects were English learners who have learned English in Surabaya in 2019. The research results showed that developing and implementing digital literacy practices in multilingual learners could improve learning English achievement. Three contributing factors to the advantages of digital technology were: comfortable access to learning resources, various learning resources, and updated learning resources. Therefore, English language learning and teaching are more exciting and challenging. Thus, digital literacy practices in multilingual learners play a crucial role in improving learning English in Indonesia.
\end{abstract}

Keywords: Digital literacy, learning English, multilingual learners

\section{INTRODUCTION}

This article describes how multilingual learners develop and implement digital literacy practices to improve their learning of English. Some previous studies relate to multilingual learners contribute to the achievement of learning English. Canagarajah (2007) states that English proficiency is in the multilingual community (learners). Many previous studies concern the achievement of learning English in multilingual learners (Martínez, 2018; Rasman, 2018; Liu, Lin, \& Wiley, 2016; Ashton, 2014; García \& Sylvan, 2011; Kramsch \& Whiteside, 2007). To determine learning English needs some requirements, such as principles, beliefs, and concepts. This article tries to concern the learners' readiness and learning processes to learn English in multilingual learners through digital literacy practices. The learners come from different mother tongues, so their readiness to learn English plays an important role. As the article aims to describe how multilingual learners implement and develop digital literacy practices to reach learning English, digital literacy practices are the activities or processes of learning English.
Eshet-Alkalai (2004) wrote some previous articles. They state that digital literacy involves more than the mere ability to use software or operate a digital device; it includes the various complex cognitive, motor, sociological, and emotional skills, which users need to function effectively in digital environments. The following articles support Eshet-Alkalai, are Kong (2014), Ng (2012), Goodfellow (2011), Martin and Grudziecki (2006), and Mason (2006).

Those articles discuss the contributions of digital literacy to reach the achievement of learning English. Digital literacy means that learners are literate digitally. It is a requirement to gain the achievement of learning English. This article focuses on how English teachers integrate teaching materials and digital technology to reach learning English. Therefore, digital literacy practices mean the learners study or learn English by using the learning management system, other recommended platforms, and social media.

\section{LITERATURE REVIEW}

Article title consists of three elements, are learning English, multilingual learners, and digital literacy. Refers 
to three factors, this article applied to use three main theories, are native language and nature of language learning, post method focuses on English users, and digital literacy.

Richards and Rogers (1986) stated that the method consisted of approach, design, and procedure. They noted that the process consisted of two theories are a native language and the nature of language learning. The native language is an account of natural language proficiency. In English language teaching (ELT), natural language proficiency is closed related to English proficiency. The nature of language learning is an account of psycholinguistic and cognitive processes involved in language learning. In English language teaching, cognitive processes consist of six (6) cognition: remembering, understanding, implementing, analysing, evaluating, and creating. This Six cognition refers to Anderson's taxonomy.

Nunan (1989), in Communicative Classroom for Designing Tasks, stated that approaches consist of the theory of language and learning. A speech theory says that language is a system for expressing meaning primary functions are interaction and communication. In English language teaching, Nunan focuses on functional language, consisting of interaction and communication. The learning theory states that activities involving real communication, carrying out meaningful tasks, and using language to promote education have meaning. In English language teaching, Nunan focuses on honest communication, which has meaning to learners promote learning.

Anderson and Krathwohl (2001) stated six (6) cognitive processes: remembering, understanding, implementing, analysing, evaluating, and creating. To develop a lesson plan, English teachers use six cognitive processes by selecting them suitable for basic competence. After finding out one of the suitable cognitions, they develop indicators as the elaboration of basic competence. Indicators consist of some action verbs to prepare to learn activities/processes in English Language Teaching.

Renandya and Widodo (2016) started searching for the best language teaching method and English use. Searching for the best language teaching method is finally known as the best method. The service and users of English are functional languages. The use means primary language function refers to Nunan as interaction and communication, and the users are interactor and communicator.

Richards, Rogers, and Nunan have some similarities and differences in relating to a Theory of Language and learning in English language teaching. They developed a Theory of Language and language learning in English language teaching. Richards and Rogers developed a Theory of native language, which focused on native language proficiency. A theory of the nature of language learning accounts for psycho-linguistic and cognitive processes involved in language learning. In English language learning and teaching, Richards and Rogers focus on psycho-linguistic and cognitive-processes. The cognitive processes are in line with Andersons' taxonomy consisting of remembering, understanding, applying, analysing, evaluating, and creating.

Nunan also developed the theory of language and learning in Designing Tasks for the Communicative Classroom. In his Theory of Language, he focuses on functional language in English language teaching. He states that language is a system for expressing meaning. The primary functions are interaction and communication. In learning theory, Nunan says that activities involving real communication, carrying out meaningful tasks, and using language have meaning to learners promote-learning. In English language teaching, Nunan states that the three main learning activities are honest communication, significant studies, and language. Activity number three is using language which has meaning to learners to promote education.

Martin and Grudzieki (2006) state that digital literacy becomes not only a critical factor in enabling participation in education, as well as employment and other aspects of social life but also a means of gaining some understanding of the world. So, digital literacy plays a significant role either in education or social life.

\section{METHOD}

This research implemented qualitative method used observation sheets and field notes to find out the data. This method is in line with the research problem and also research questions. The design of the research is explanatory. Participants are five students from Indonesian (Javanese, Madurese, and Makassar), Thailand, and Korea. Through descriptive research, developing and implementing digital literacy practices can improve learning English in multilingual learners. The researcher explains the development and implementation of digital literacy practices, comprehensively and chronologically.

\section{FINDINGS AND DISCUSSION}

This part explains and discusses the findings and discussions. One is to describe how English teachers develop digital literacy practices to improve learning English in multilingual learners. To clarify how English teachers implement digital literacy practices to enhance learning English in multilingual learners.

\subsection{Developing Digital Literacy Practices to Improve English Learning Achievement of Multilingual Learners}

Learning English achievement refers to Richards and Rogers (1986) theory of native language in Approaches and Methods in Language Teaching and Nunan (1989) Theory of language in Designing Tasks for the 
Communicative Classroom. Richards and Rogers stated that learning English is the learners can master English proficiency (Theory of Native Language). In Theory of Language - Designing Tasks for the Communicative Classroom, Nunan stated that learning English is the learners can master the functional language consisting of interaction and communication (the learners can master interaction and communication).

To find out the purposes of learning English, English teachers should develop lesson plans and implement them in English language teaching. In developing lesson plans, English teachers design English classes by integrating learning materials and technology or developing lesson plans. Six elements in developing lesson plans are the method's general and specific objectives, a syllabus model, types of learning and teaching activities, learner roles, teacher roles, and instructional materials' role.

In the digitization era, changes in some principles have occurred, including in education. It has been happened in Indonesia, too. The shifting paradigm of English language teaching is progressing in Indonesia. English Language Teaching has been affected by two latest changes, English use and users, and the search for the best language teaching methods (Renandya \& Widodo, 2016). Language teaching has also changed because English use and users contribute to the latest English Language Teaching change. One of the approaches of English Language Teaching is a Theory of the nature of language learning (Richards \& Rodgers, 1986). It relates to a Theory of the Nature of language learning automatically relates to a Theory of native language. However, this article focuses on the nature of language learning. The use and English users are, mainly because English users are native English, but most multilingual learners, specifically non-native English.

The search for the best language teaching methods has also changed because the goal of language teaching had changed. The purpose of language teaching and language teaching methods have a close relationship and related to each other. In chronological order, the Use and users of English have shifted from native English to nonnative English. The shifting has influenced the goal of learning and teaching English. The changing of education and teaching English has also influenced searching for the best language teaching methods.

Those are familiar with digital literacy practices. Those are not familiar, yet state that they agree, the majority of the use and user of English are non-English native speakers. Nevertheless, those who are not aware yet have some different points of view. They focus on the approach of the native language. They still believe that language proficiency has to refer to the theory of the native language.

On the other hand, those familiar with digital literacy practices focus on the different approaches, the nature of language learning. They continue their argument of the
Use and user of English, as stated in the following explanation. Use refers to the activities of using English are increasing. It consists of English in education, industry, economy, politics, culture, society. It causes an increase in the activities of people day by day. The activities are running well if they can communicate with each other by using international language directly (faceto-face communication) or indirectly (communication through using tools, such as smart-phones and computers). The role of English is as the International language and also as a lingua franca. In those activities, people communicate with each other by using English in many aspects of their life.

Relating to the users of English are familiar with the practices of digital literacy. They stated that the users refer to the number of people involved in their activities increasing. The increasing activities are in line with the increasing of people who involve those activities. Two factors are the use, and English users are supported by technological innovations, either in education or noneducation. In education, the use of educational technology and technology-enhanced language learning increases significantly day by day. E-learning and the user of computer-assisted language learning (CALL) and mobile-assisted language learning (MALL) also increase in this era. Seven benefits of using CALL are: multimodal practice with feedback, individualization in a large-class, pair and small group work on projects, either collaboratively or competitively, the fun factor, variety in the resources available and learning styles used, exploratory learning with large amounts of language data, and real-life skill-building in computer use (Brown, 2000, p. 145).

Technological innovations, the advantages of digital technology, contribute to multilingual learners getting more comfortable access to learning resources /materials, various learning resources/materials are available, and learning resources/materials are updated. In English language teaching, the English teachers' sources are not single anymore, the English teachers, but it is increasing, refers to educational technology and technologyenhanced language learning. So, the number of nonEnglish native speakers is increasing day by day, which influences the shifting or changing the nature of language learning.

It relates to the English users; most learners are multilingual learners of young people or the young generation. Digital technology, one of the advantages is the variety of learning resources/materials are available. It contributes to multilingual learners to choose or select the availability of learning resources/materials. Therefore, multilingual learners are the young generation, so the young age is called a digital native. Meanwhile, the old generation is called a digital immigrant. The increasing number of English users has influenced the shifting of the goal of learning and teaching English. 
Dealing with learning English, multilingual learners, as most learners are welcome to, the nature of language learning has changed. The success does not refer to English native speakers anymore, more specifically in speaking. The users of non-English natives or multilingual learners have a larger number rather than English native. In spoken communication, the probabilities communicate with the users of non-English natives are the lots number rather than English native. So the goal of learning English refers to the nature of language learning, stating the success is the learners' ability to communicate with their spoken partners in English.

\subsection{Implementing Digital Literacy Practices to Improve English Learning Achievement of Multilingual Learners}

To implement lesson plans, English teachers should manage three main activities: face-to-face (virtual) meetings, structural assignment, and independent learning. In the face-to-face (virtual) meeting, English teachers deliver learning material in every face-to-face meeting using a learning management system (LMS). In structural assignments, English teachers develop each learning material, which has an enclosed with some duties. English teachers motivate learners to become more active in independent learning, either improve their learning English or do their tasks using a learning management system (LMS). Meanwhile, learners' learning English skills are a processor, performer, initiator, and problem solver. The practices of digital literacy stimulate learners to become more active in learning English. As processors, learners are supposed to become more active learners in learning activities using the learning management system. The next role is to perform; learners are supposed to become more active learners in learning activities so, their English performances are increasing day by day. The third role is the initiator; the learners are supposed to become more independent learning by using the learning management system. Moreover, as a problem solver, learners are supposed to become a more active learner in identifying, classifying, and finding out solutions relating to their learning problem. Later, they are literate digitally so, the learners can find out the benefits of digital technology are easier to access learning resources/materials, various learning resources/materials are available, and learning resources/materials are updated. Therefore, they can be independent learners. Activity number three, independent learning, which has been managed by the English teachers, is reaching.

Five components are involved in learning and teaching activities: learners, teachers, learning materials, media, and assessments. Learners increasingly contribute an essential role to begin or start the new paradigm of English language learning. Among the components in learning activities, learners play critical parts to become independent learners to have a new paradigm in learning English. Some changes have already occurred in learning
English. Now the paradigm of learning English is English for International Language rather than English as a foreign language. Learners have a significant contribution to becoming independent learners by having a comprehensive understanding of digital technology's advantages. They are easier to access the learning resources/materials, the various learning resources/ materials are available, and the learning resources/ materials are updated. Independent learners contribute to the shifting paradigm of English language learning in Indonesia. It states that the current English learning is affected by two latest changes: The Use and users of English; and the search for the best language teaching method. Therefore, in the digitization era, digital technology has changed the theory of the native language. If learners and students learn English, they have to follow language proficiency as English natives.

To find out the best language teaching methods does not depend on the theorists' learning language but now tends to invite the English teachers as a practitioner meaning that the English teachers are an expert in teaching English. Based on a theory of the nature of language learning, English teachers have a more comprehensive understanding of teaching English rather than theorists' language learning. The English teachers are a part of integrative activities in studying and teaching English, so they have more than theorists' learning languages. English teachers still play significant roles in implementing the best language teaching methods in the classroom.

To accommodate the shifting of learning English, what kind of method is suitable for learning teaching activities, the Post-method is answering. It has three dimensions: particularity, practicality, and possibility (Kumaradivelu, 2006). The Post-method is suitable for an English teacher who has the autonomy to select what the appropriate methods are. Three dimensions are in Post-method, which are ideal for English teachers' autonomy is. Particularity emphasizes local exigencies and lived experiences. Lived experiences belong to the English teachers, not other people, such as theorists' language learning. Practicality emphasizes action research. It means that to differentiate between theorists' theory and teachers' theory. Teaching English is related to daily activities, so English teachers have a comprehensive understanding of managing learning and teaching activities in the classroom. The possibility is concerned with language ideology and learner identity. The dimension of the case is suitable for learning L2. Language ideology is related to culture. Culture needs understanding about the values of L2. Learning L2 means that the learners have the possibility; the underlined word possibility is similar to challenges and opportunities to know and understand the language ideology of L2. Teaching L2, English teachers have to take one step forward knowing and understanding the language ideology of L2 compare with learners L2. So, Postmethod accommodates English teachers' autonomy. 
Finally, the two latest changes, English use, and users and the search for the best language teaching methods, have influenced the shifting paradigm of English language teaching in Indonesia. Two main factors have also changed the goal of learning English nowadays. So, the English learning changes have influenced the search for the best language teaching methods, the Post-method.

\section{CONCLUSION}

Based on the findings and discussions, the researcher concludes with two main items. They are the descriptions of how English teachers develop digital literacy practices to improve learning English in multilingual learners and implement digital literacy methods to enhance learning English in multilingual learners. Refer to the conclusion that suggestions can be delivered for further researchers. English teachers can develop and implement digital literacy practices to improve learning English in young learners and become independent learners. Finally, developing and implementing digital literacy methods to enhance learning English in young learners, English teachers can develop and implement digital literacy in distance learning.

\section{REFERENCES}

Anderson, L., W., \& Krathwohl, D. R. (2001). A taxonomy for learning, teaching, and assessing: A revision of Bloom's taxonomy of educational objectives. Boston: Allyn \& Bacon.

Ashton, K. (2014). Using self-assessment to compare learners' reading proficiency in a multilingual assessment framework. System, 42(1), 105-119. doi: 10.1016/j.system.2013.11.006

Brown, H. D. (2000). Teaching by principles: An interactive approach to language pedagogy. California: Allyn \& Bacon.

Canagarajah, S. (2007). Lingua franca English, multilingual communities, and language acquisition. Modern Language Journal, 91(1), 923-939. doi: 10.1111/j.1540-4781.2007.00678.x

Eshet-Alkalai, Y. (2004). Digital literacy: A conceptual framework for survival skills in the digital era. Journal of Educational Multimedia and Hypermedia, 13(1), 93-106.

García, O., \& Sylvan, C. E. (2011). Pedagogies and practices in multilingual classrooms: Singularities in pluralities. Modern Language Journal, 95(3), 385-400. doi: 10.1111/j.1540-4781.2011.01208.x

Goodfellow, R. (2011). Literacy, literacies, and the digital in higher education. Teaching in Higher Education, 16(1), 131-144. doi: $10.1080 / 13562517.2011 .544125$
Kong, S. C. (2014). Developing information literacy and critical thinking skills through domain knowledge learning in digital classrooms: An experience of flipped classroom strategy. Computers, and Education, $\quad 78, \quad 160-173 . \quad$ doi: 10.1016/j.compedu.2014.05.009

Kramsch, C., \& Whiteside, A. (2007). Three fundamental concepts in second language acquisition and their relevance in multilingual contexts. Modern Language Journal, 91, 907-922.

Kumaradivelu, B. (2006). Understanding language teaching from method to post method. San Jose: Laurence Erlbaum Assiciates, Inc.

Liu, N., Lin, C. K., \& Wiley, T. G. (2016). Learner views on English and English language teaching in China. International Multilingual Research Journal, 10(2), 137-157. doi: $10.1080 / 19313152.2016 .1147308$

Martin, A., \& Grudziecki, J. (2006). DigEuLit: Concepts and tools for digital literacy development. Innovation in Teaching and Learning in Information and Computer Sciences, 5(4), 249 267.

Martínez, R. A. (2018). Beyond the English learner label: Recognizing the richness of bi/multilingual students' linguistic repertoires. Reading Teacher, 71(5), 515-522. doi: 10.1002/trtr.1679

Mason, R. (2006). Literacy in the digital age. British Journal of Educational Technology, 37(2), 315315. doi: 10.1111/j.1467-8535.2006.00602_10.x

$\mathrm{Ng}$, W. (2012). Can we teach digital natives digital literacy? Computers and Education, 59(3), 10651078. doi: 10.1016/j.compedu.2012.04.016

Nunan, D. (1989). Designing tasks for the communicative classroom. Cambridge: Cambridge University Press.

Rasman, R. (2018). To trans language or not to trans language? The multilingual practice in an Indonesian EFL classroom. Indonesian Journal of Applied Linguistics, 7(3), 687-694. doi: 10.17509/ijal.v7i3.9819

Renandya, W. A. \& Widodo, H. P. (2016). English language teaching today: Linking theory and practice. London: Springer.

Richards, J. C., \& Rogers, T. S. (1986). Approaches and methods in language teaching. Cambridge: Cambridge Language Teaching Library. 